\title{
Application of geostatistical analyst methods in discovering concealed gold and pathfinder elements as geochemical anomalies related to ore mineralisation
}

\author{
Philemon Lindagato ${ }^{1}$, Yongjun Li ${ }^{1,2 *}$, Gaoxue Yang ${ }^{1,2}$, Fenghao Duan ${ }^{1}$, \\ Zuopeng Wang ${ }^{1}$ \\ ${ }^{1}$ School of Earth Science and Resources, Chang'an University, Xi' an 710054, China \\ ${ }^{2}$ Key Laboratory for the Study of Focused Magmatism and Giant Ore Deposits, MLR, Xi' an 710054, China \\ *corresponding author; e-mail: yongjunl@chd.edu.cn
}

\begin{abstract}
The study area in the West Junggar Basin is known to be rich in hydrothermal gold deposits and occurrences, even though there has been minimum exploration in the area. It is here hypothesised that this area could host more gold deposits if mineral exploration methods were to be reinforced. This research is aimed at identifying geochemical anomalies of $\mathrm{Au}$, and determining possible factors and conditions which facilitate the formation of anomalies by referring to As and $\mathrm{Hg}$ as gold pathfinders. Geostatistical analyst techniques have been applied to 9,852 stream sediments and bedrock data collected on a total surface of $1,280 \mathrm{~km}^{2}$ of West Junggar, Xinjiang (northwest China). The kriging interpolation and quantile-quantile plot methods, combined with statistical methods, successfully identified both Au and its pathfinders' anomalies. In the present study, median was considered as background values (10.2 ppm for As, 9.13 $\mathrm{ppb}$ for $\mathrm{Hg}$ and $2.5 \mathrm{ppb}$ for $\mathrm{Au}$ ), whereas the $95^{\text {th }}$ percentile were threshold values (28.03 ppm for As, $16.71 \mathrm{ppb}$ for $\mathrm{Hg}$ and $8.2 \mathrm{ppb}$ for $\mathrm{Au}$ ) and values greater than thresholds are geochemical anomalies. Moreover, the high concentrations of these three discovered elements are caused primarily by hydrothermal ore mineralisation and are found to be controlled mainly by the Hatu and Sartohay faults of a northeast-southwesterly direction as well as their related secondary faults of variable orientation, which facilitate the easy flow of hydrothermal fluids towards the surface resulting in the formation of geochemical anomalies. Most of anomalies concentration of Au are found near the mining sites, which indicates that the formation of new Au anomalies is influenced by current or previous mining sites through geological or weathering processes. In addition, the low concentration of gold and its pathfinders found far from active gold mine or faults indicates that those anomalies are formed due to primary dispersion of hosting rock.
\end{abstract}

Key words: Geochemical anomalies, geostatistical analyst, kriging interpolation, quantile-quantile plot

\section{Introduction}

Many assessments of natural resources have been used multivariate statistical or numerical-statistical approaches as the method of discovering concealed deposits (Singer et al., 2001). Most of such studies have proved that the spatial distribution of ore deposits follows the fractal distribution during geochemical anomaly identification (Li et al., 2002, 2003; Raines, 2008; Deng et al., 2009; Ma et al., 2014, 2016). Moreover, geostatistical methods have been found to be a more suitable technique to assess 
spatial distribution of data. They are advantageous methods because they predict the values of variables in non-sampled areas and render a logical association within their prediction (Monego et al., 2008; Ramos \& Abreu, 2010).

The most commonly used geostatistics are those of Gstat and ArcGIS software. The Gstat package is used for multivariable geostatistical prediction (Pebesma \& Wesseling, 1998). It performs many geostatistical analyses such as computing variogram and cross variogram modelling, interpolation, simple/ordinary/universal kriging, cross-validation, trend modelling, simulation and visualisation, indicator kriging and simulation, block kriging and mapping (Abreu \& Ramos, 2010).

The analytical methods used in the present paper are geostatistical analyst extension of ArcGIS. Geostatistical analyst is widely used for commercial purposes because it supports easy graphical interface. ArcGIS performs an extensional geostatistical analysis and renders global and local interpolation approaches as well (Inverse Distance Weight IDW, trend surface, global and local polynomial, kriging and co-kriging) (Abreu \& Ramos, 2010). The kriging method was chosen as a good geostatistical analyst to analyse and interpret data in this research because it quantifies the spatial structure known as variography which uses two points to measure the spatial relationships of the variables (Bossew et al., 2014) and it provides a prediction of unknown values. It is a quick interpolator that is based on the variogram-fitted model, configuration of spatial data and measured sample points to predict the unknown value (Ashok et al., 2007). These kriging interpolation techniques have been proved to be the best way to analyse spatial geochemical data (Abreu \& Ramos, 2010), to create a continuous surface by either using measured sample points or the polygon centroid and, finally, to predict the values to non-sampled surface. Geostatistical analyst is a quick ArcGIS extension method to create a surface due to the reason that it provides defaults and a variety of tools to determine the parameters. Its statistical models permit map outputs with predictions, predicted standard error, standard error of indicators and probability.
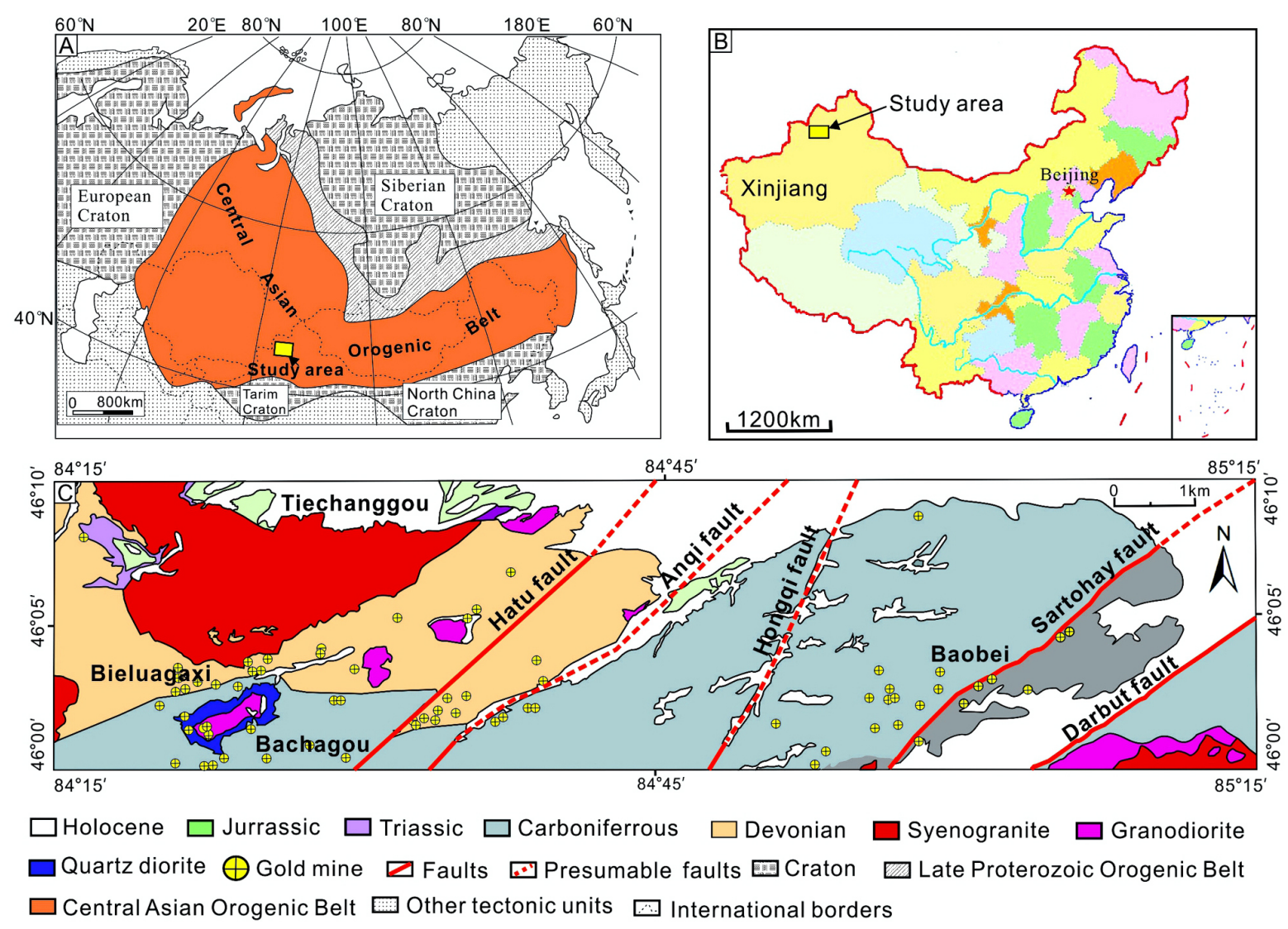

Fig. 1. Map showing the geological structure and distribution of gold deposits in the study area. A - Simplified map illustrating the location of study area relative to the Central Asian Orogenic Belt (CAOB) (Jahn et al., 2000); B Location of the study area on the map of China; C - Simplified geological map of the study area in West Junggar, Xinjiang (northwest China). 
In addition, the geostatistical analyst tool also provides an understanding of qualitative and quantitative aspects of the data to the users. It provides full access to predict and model the spatial distribution based on statistics and exploration tools. After processing geochemical data, ArcGIS geostatistical analyst yields opportunities to investigate, visualise and create surfaces for advanced spatial analysis (Ashok et al., 2007). Well-applied geostatistics are the most powerful tool to accomplish the main target of analysing geochemical data which is to describe geochemical and geological processes by using statistical variations of data (Aitchison, 1986; Bonham-Carter et al., 1988, 1989; Cheng et al., 2000; Carranza, 2010; El-Makky, 2011; El-Makky \& Sediek, 2012; Grunsky et al., 2014; Luz et al., 2014). It must be assisted by the ability of locating and identifying anomalies from the background which is most important when interpreting and analysing data of geochemical exploration (Zuo et al., 2009).

For discovering the potential of concealed ore bodies, it is crucial to identify both favourable geological conditions for ore formation and reliable geoscientific data. For maturely explored areas, exploration strategy as based on a dynamic understanding of the mineralisation system is effective in predicting the location of ore deposit anomaly (Liu et al., 2004).

The study area is situated in the southwest of the Central Asian Orogenic Belt (CAOB) (Fig. 1A), more precisely in West Junggar, in the Xinjiang Autonomous Region of China (Fig. 1B). This region has had a complex tectonic evolution and is known to be the source of numerous minerals making it an attractive area for geologists (Yakubchuk, 2004; Seltmann \& Porter, 2005; Shen et al., 2013, 2016; Cao et al., 2015).

Based on the geological background of this area, it seems that it has more ore deposits in comparison to those discovered; probably, previous exploration methods used in this region were not sufficient. This is one of the reasons for conducting the present study, so as to enhance the exploration for the purpose of discovering further hidden ore deposits.

The aim of the present paper is to identify geochemical anomalies of $\mathrm{Au}$ and to determine the possible factors and conditions facilitating the formation of its anomalies by referring to $\mathrm{As}$ and $\mathrm{Hg}$ as its pathfinder elements. Geostatistical analyst methods have been applied to 9,852 bedrock and stream sediment geochemical data collected by the No.1 Geological Survey Team of the Xinjiang Bureau of Geology and Mineral Resource Exploration, over a total surface of $1,280 \mathrm{~km}^{2}$. Factors that influenced the formation of geochemical anomalies in the study area are also discussed below.

\section{Geological background}

The study area of Xinjiang consists of two basins: the Junggar Basin and Tarim Basin, which are divided by three parallel mountain ranges, oriented east-west and north-south, respectively. These ranges are the following: Altay Mountains (i.e., Gold Mountain in the local language), Tianshan Mountains and Kunlun Mountains. Samples have been collected from the west of the Junggar Basin which is located within the southwest of $\mathrm{CAOB}$ and includes the Gurbantunggut Desert (Chow, 2009). It is one of the most concentrated areas of gold mining in Xinjiang, and it is also one of the key areas in chromite production in China (Zhu, 2014).

Furthermore, the study area contains rivers from which stream sediment samples were collected (Fig. 2). The folds in this area are more developed; five main folds are distinguished, as follows: the Aketamu syncline fold, the Keketale syncline fold, the Bieluagaxi anticline fold, the Hongqi syncline fold and the Hongshan syncline fold. In addition, the fault structures are also extremely developed and contain five main faults, the Hatu fault, Anqi fault, Hongqi fault, Sartohay fault and Darbut fault. These faults generally show a northeasterly trend. They control the distribution of strata, intrusive rocks, minerals and regional geochemical anomalies. Many secondary faults are well developed. Based on their direction, they could be divided into three groups: northeast, northwest and east-west. All major faults in this area are associated with well-developed subsidiary fractures, which is the key control of lithologies and magmatism, and it is also important in locating mineralisation areas (Shen et al., 2007; Chen et al., 2010). This proves that the West Junggar has a high potential for future mineral exploration. In this area, the two greatest volcanics-hosted gold deposits (the Kuoerzhenkuola and Buerkesidai gold deposits) have been discovered, to which different models have been applied (Yin et al., 1996; Guo, 1997; Wang et al., 2004). The extensive study done by Shen et al. (2007) on the geology, geochemistry and geochronology concluded that both have the same genesis and are classified as volcanogenic hydrothermal gold deposits. Numerous copper and gold ores have been discovered in the West Junggar even though this area has only been subjected to minimum exploration; this means that the area should be taken into consideration as particularly potential for future mineral exploration and discovery of copper and gold deposits. All mineral deposits in the West Junggar region of the northern Xinjiang Province are related to recognised geochemical anomalies (Yuan et al., 2015). 


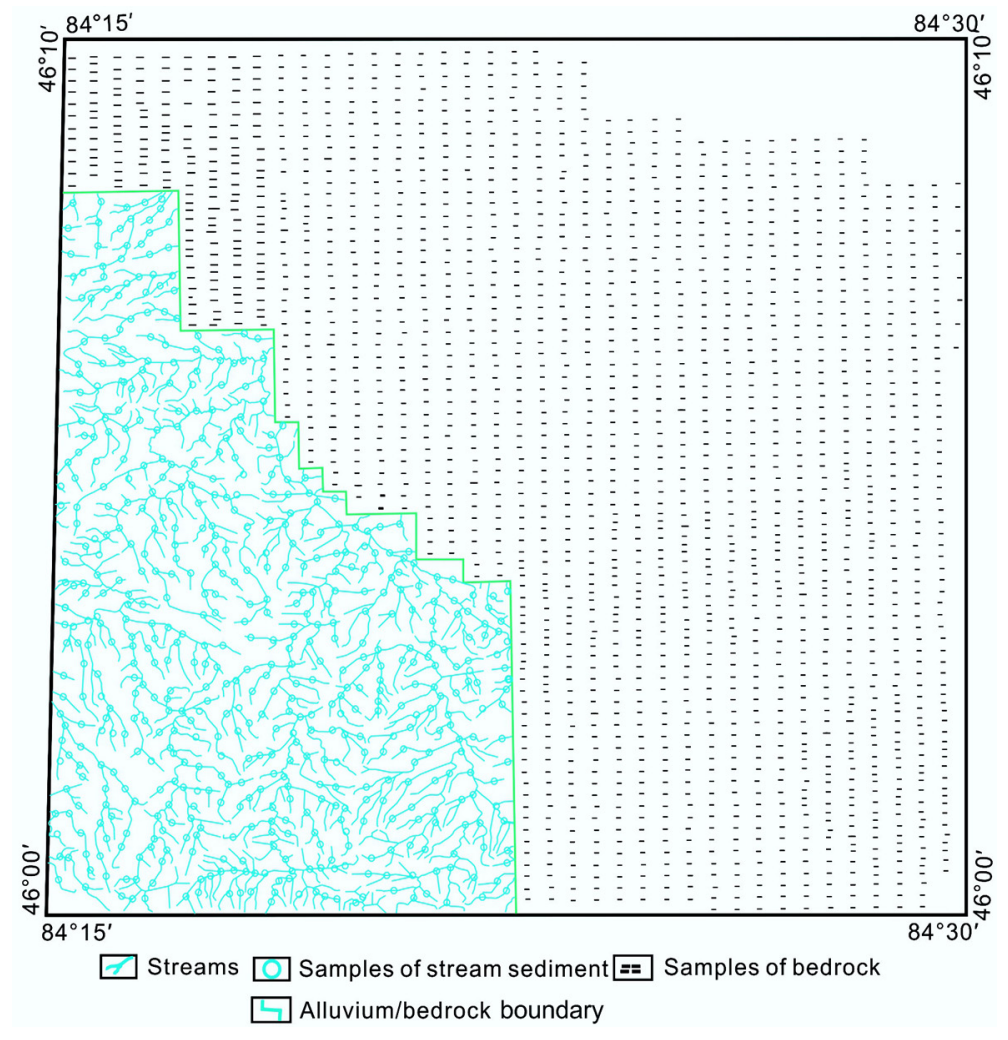

Fig. 2. Map of the eastern part of the study area, showing the location of the alluvium and bedrock samples and their boundary.
Volcanic rocks in the study area are better developed and the Middle Devonian-Upper Carboniferous strata are extensive. The volcanic activity was dominated by eruption explaining why the lithological composition mainly is volcanic clastics. The Middle Devonian is a volcanic complex deposited by marine volcanic debris sediments, which are mostly composed of basalt-andesite-dacite-rhyolite series. The rock series is predominantly calc-alkaline. The lithology of this area is composed mainly of tuff, tuff crumbs, siliceous rock, tuffaceous sandstone, tuffaceous silty mudstone, andesite and others. Some rocks around the Sartohay fault were probably formed in island arc during the Late Carboniferous (Liu et al., 2009a). Geochemical characteristics of the Baobei volcanic rock have shown it to be from an oceanic island arc (Zhu \& Feng, 1994; Wang, 2005).

According to Yin et al. (2010), mineralisation and tectonic transition in West Junggar were generated during the Carboniferous and its strata consist mainly of a succession of Devonian to Carboniferous volcano-originated sediments. This region is dominated by well-developed volcanic rocks (Han et al., 2006; Geng et al., 2009). Its tectonics, discussed in general by Geng et al. (2009), are reflected in high-temperature, low-pressure magmas of Late Carboniferous age. Its granitic intrusions are mainly of the I- and A-types (Zhang et al., 2006;
Yuan et al., 2006; Su et al., 2006; Yin et al., 2010), on account of the high temperature regime from the lithospheric mantle metasomatised (Chen \& Arakawa, 2005; Tang et al., 2012). The structure shows that this region has many faults that are oriented in northeasterly and southwesterly directions (Zhang et al., 2001; 2012; Yang et al., 2017) on which granitoids and ophiolitic mélanges are found (Yang et al., 2013, 2015, 2017); this is the most valuable source of copper and gold in northwest China (Rui et al., 2002; Zhu et al., 2007) (Fig. 1C). The lithostratigraphy of this region mostly documents volcanic-sedimentary strata with a close relationship to faults. Its mineralisation is due to the complex activities of tectonics and magmatism (Yang et al., 2015, 2017).

Various mineral deposits have been discovered in this area, and the most often recognised are porphyry copper and gold deposits. Moreover, this region also is rich in nickel, chromite, tungsten and molybdenum (Liu et al., 2009a; Shen et al., 2013, 2016; Zhu, 2014; Cao et al., 2015). Many chromite deposits were found in the Darbut ophiolitic belt (Shen et al., 2015) and in its east, there are the Sartohay deposits with high-Al podiform chromite ores (Tan \& Zhu, 2010). The largest gold ore deposits of West Junggar are concentrated in the Hatu zone (Shen et al., 1993) and are classified as quartz veins ore and altered rocks ore (Shen et al., 2015) and explained by Rui et al. (2002) as controlled orogenic 
gold deposits. Apart from being dominated by gold and chromite, this region is an oilfield for China as well as a potential exploration for $\mathrm{Cu}-\mathrm{Au}-\mathrm{Pb}-\mathrm{Zn}$. In addition, this region has complex tectonic and magmatic activities which have resulted in numerous mineralisations (e.g., porphyry $\mathrm{Cu}$ and $\mathrm{Au}$ deposits, porphyry-quartz vein-greisen tungsten and Mo deposits, copper-nickel sulphide deposits and podiform chromite deposits) (An \& Zhu, 2009; Liu et al., 2009b; Zhu, 2014).

\section{Material and methods}

Geochemical investigations include two main steps: sampling and analysing the concentration of chemical elements from the sampling region. The method used to collect samples until final data are obtained will determine the quality and usefulness of geochemical data. In addition, geochemical and geological explorations are the cheapest methods compared to other methods used in exploration (Mwangi, 2013).

Prior to sample collection, the study area was divided into four equal parts. In the study area of $1: 50,000$ geochemical surveys scale of $1,280 \mathrm{~km}^{2}$, the total collected samples were 9,852, inclusive of 566 stream sediment samples collected in western part of the study area and 9,286 bedrock samples collected in the remainder of the study area using GPS, compass and other tools. The original weight of the collected samples on the field in bed rock was generally 300 gr on a regular spacing of $40 \mathrm{~m}$ with a density of $5.25 / \mathrm{km}^{2}$ and $400 \mathrm{gr}$ with a density of $8.12 / \mathrm{km}^{2}$ for the linear water system, where the distance between the two sampling points was generally not less than $300 \mathrm{~m}$ and not more than $800 \mathrm{~m}$. A total of 9,852 sampling sites were completed, with an average sampling point density of $7.87 / \mathrm{km}^{2}$. The samples originate from rocks of Holocene, Jurassic, Triassic, Carboniferous and Devonian age and from granites and diorites. Figure 2 represents only the western part of the study area where stream sediment samples were collected, and the unillustrated part contains merely bedrock samples. Following all inspections, the overall quality of samples fit the requirements of the 1:50,000 geochemical survey scale. During chemical analysis, various types of instruments participating in the analysis were calibrated by the Institute of Regional Metrology and Testing to ensure the normal operation in the analysis of large quantities of samples. The instruments and measurements used in this analysis are listed in Table 1 . The concentration values of 15 elements were measured in this study $(\mathrm{Au}, \mathrm{Ag}, \mathrm{Cu}, \mathrm{Pb}, \mathrm{Zn}, \mathrm{As}, \mathrm{Sb}$, $\mathrm{Hg}, \mathrm{W}, \mathrm{Sn}, \mathrm{Mo}, \mathrm{Bi}, \mathrm{Cr}, \mathrm{Co}, \mathrm{Ni}$ ) and concentrations of As, $\mathrm{Hg}$ and $\mathrm{Au}$ from these samples have been taken into consideration for identifying their anomalies and attempting to predict factors and relationships between their anomalies. During data analysis, descriptive statistics have been calculated, including minimum, maximum, sum, mean, standard devia-

Table 1. Analysis of 15 elements measured in the present study.

\begin{tabular}{lccccc}
\hline Element & Analytical method & $\begin{array}{c}\text { Detection limit } \\
(\mu \mathrm{g} / \mathrm{g})\end{array}$ & $\begin{array}{c}\text { Rate of data } \\
\text { report }(\%)\end{array}$ & $\begin{array}{c}\text { Precision } \\
\text { RSD } \%\end{array}$ & $\begin{array}{c}\text { Accuracy } \\
\sum \Delta \operatorname{lgC}\end{array}$ \\
\hline $\mathrm{As}$ & $\mathrm{AFS}$ & 0.50 & 100.0 & 6.5 & -0.023 \\
$\mathrm{Sb}$ & $\mathrm{AFS}$ & 0.08 & 100.0 & 7.8 & -0.087 \\
$\mathrm{Bi}$ & $\mathrm{AFS}$ & 0.03 & 100.0 & 5.8 & -0.021 \\
$\mathrm{Hg}$ & $\mathrm{AFS}$ & 0.004 & 97.7 & 5.6 & -0.015 \\
$\mathrm{Cu}$ & ICP-OES & 0.50 & 100.0 & 7.7 & -0.114 \\
$\mathrm{Zn}$ & ICP-OES & 5.0 & 100.0 & 6.4 & -0.085 \\
$\mathrm{Co}$ & ICP-OES & 0.80 & 100.0 & 9.4 & -0.135 \\
$\mathrm{Ni}$ & ICP-OES & 0.80 & 100.0 & 7.4 & -0.216 \\
$\mathrm{Cr}$ & ICP-OES & 2.5 & 96.8 & 10.7 & -0.327 \\
$\mathrm{~W}$ & POL & 0.25 & 98.9 & 12.5 & 0.089 \\
$\mathrm{Mo}$ & POL & 0.30 & 96.1 & 14.6 & -0.133 \\
$\mathrm{Ag}$ & AES & 0.025 & 100.0 & 8.5 & -0.091 \\
$\mathrm{Sn}$ & AES & 0.70 & 99.0 & 9.0 & 0.035 \\
$\mathrm{~Pb}$ & AES & 3.0 & 99.5 & 7.4 & 0.006 \\
$\mathrm{Au}$ & Graphite oven & 0.0003 & 100.0 & - & - \\
\hline
\end{tabular}

AFS: Atomic Fluorescence Spectrometry.

ICP-OES: Inductively Coupled Plasma Optical Emission Spectrometer.

POL: Oscillopolarography.

AES: Spectrum Deep-Hole Electrode Method. 

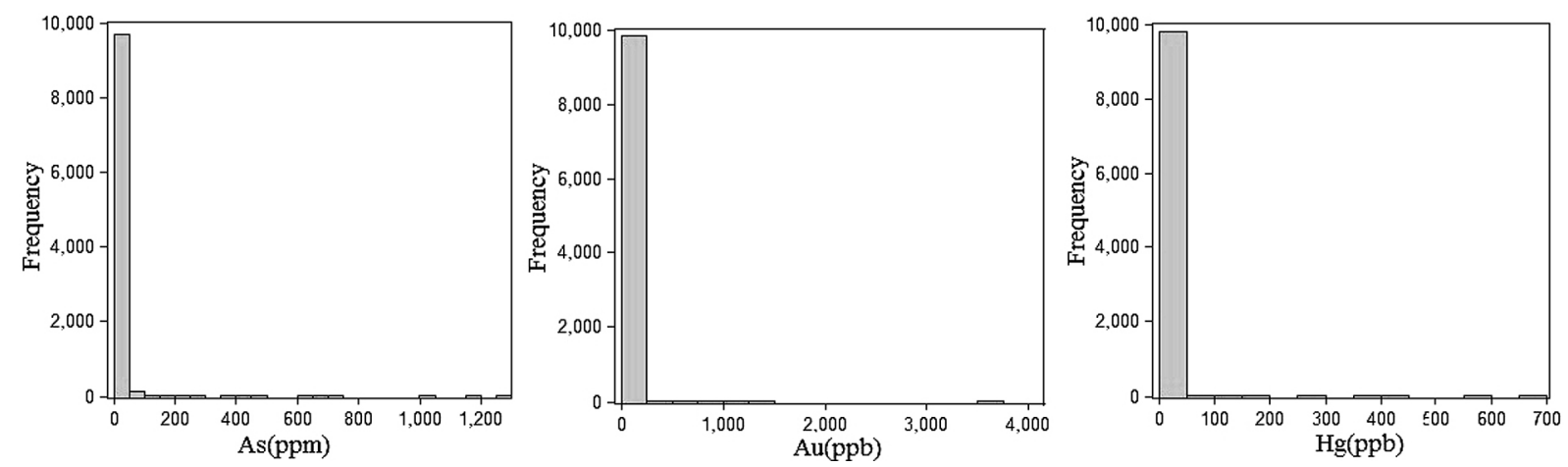

Fig. 3. Histogram of raw material data.

tion, variance, skewness and kurtosis. By observing the properties of these data (Fig. 3), it was indicated that they are not normally distributed; thus, it was necessary to normalise them using log-transformation and quantile-quantile plot. These statistical calculations were performed using the Statistical Package for the Social Sciences (SPSS) and Eviews.

In order to analyse precisely the geochemical characteristics and anomalies of the elements by ArcGIS mapping, the original data were transformed into $0.5 \mathrm{~km} \times 0.5 \mathrm{~km}$ window data (grid size $0.5 \mathrm{~km} \times 0.5 \mathrm{~km}$, with a radius of $1.5 \mathrm{~km}$ calculated by exponential weighting method). The geostatistical analyst applied was the kriging method, which is based on the autocorrelation between two points of a given variable as shown by:

$$
z(s)=\mu(s)+\varepsilon(s)
$$

where $\mu(s)$ represents a deterministic trend, $\varepsilon(s)$ indicates a random autocorrelation error, $\mathrm{s}$ being the location of a point. The existence or absence of directional trend measured by $\mu(s)$ is the basis of selecting the kriging method. The ordinary kriging is applied when the directional trend is unknown, while simple kriging is applied for known directional trends (Ashok et al., 2007).

Due to the unknown directional trend, the applied ordinary kriging formula is generalised as:

$$
Z^{*}(u)=\sum_{a=1}^{n(u)} \lambda_{a}(u) Z\left(u_{a}\right)+\left|1-\sum_{a=1}^{n(u)} \lambda_{a}(u)\right| m
$$

the $Z^{*}(u)$ stands for the ordinary kriging estimate at location $u, n(u)$ indicates the number of data used at neighbourhood location, $Z\left(u_{a}\right)$ are the $n$ measured data at locations ua close to location $u$. $m$ represents the mean distribution, $\lambda_{a}(u)$ is the weight for location calculated based on variogram model given by:

$$
\lambda(h)=\frac{1}{2 n} \sum_{i=1}^{n}\left(z\left(u_{i}\right)-z\left(u_{i}+h\right)\right)^{2}
$$

where, $n$ equals to the number of data pair separated by distance $h$, both $z\left(u_{i}\right)$ and $z\left(u_{i}+h\right)$ are the values of data at given locations also separated by distance $h$.

During interpolation, the five steps have been applied, as follows: selection of geostatistical analyst method, selection of the kriging type, application of semivariogram/covariance modelling, searching neighbouring data points and then predicted values vs measured values. Semi-variogram/ covariance modelling was applied on spatial autocorrelation of the data which statistically display the correlation of nearest data points. Some of the data are far from measured data points and have no correlation to the predicted locations. So, these data should not be used to predict the value of unmeasured locations.

\section{Results}

\subsection{Statistical analysis}

A summary of statistical calculation of $\mathrm{As}, \mathrm{Hg}$ and $\mathrm{Au}$ elements data is shown in Table 2 where the high skewness and kurtosis from the concentration

Table 2. Statistical analysis of $\mathrm{As}, \mathrm{Hg}$ and $\mathrm{Au}$ data from the study area.

\begin{tabular}{|lcrrrrrrrc}
\hline Elements & $\mathrm{N}$ & Minimum & Maximum & \multicolumn{1}{c}{ Sum } & Mean & Std. dev. & Variance & Skewness & Kurtosis \\
\hline $\mathrm{As}(\mathrm{ppm})$ & 9852 & 0.54 & 1802.00 & 137157.96 & 13.92 & 34.98 & 1223.60 & 28.99 & 1124.35 \\
$\mathrm{Hg}(\mathrm{ppb})$ & 9852 & 2.50 & 1054.00 & 103395.00 & 10.50 & 16.29 & 265.48 & 41.15 & 2184.49 \\
$\mathrm{Au}(\mathrm{ppb})$ & 9852 & 0.00 & 5748.00 & 53482.35 & 5.43 & 73.97 & 5472.58 & 61.20 & 4292.34 \\
\hline
\end{tabular}


Table 3. Descriptive statistics of log-transformed of As, $\mathrm{Hg}$ and Au.

\begin{tabular}{lcrrrrlcrr}
\hline Elements & $\mathrm{N}$ & Minimum & Maximum & \multicolumn{1}{c}{ Sum } & \multicolumn{1}{c}{ Mean } & Std.dev. & Variance & Skewness & Kurtosis \\
\hline Log-As & 9852 & -0.69315 & 7.496652 & 23071.47 & 2.342281 & 0.62105 & 0.386 & 0.861284 & 8.09984 \\
Log-Hg & 9852 & 0.91629 & 6.960348 & 22052.36 & 2.238819 & 0.375295 & 0.141 & 1.914306 & 16.17116 \\
Log-Au & 9852 & -1.60944 & 8.656607 & 8384.94 & 0.851263 & 0.897654 & 0.806 & 0.573932 & 6.40775
\end{tabular}
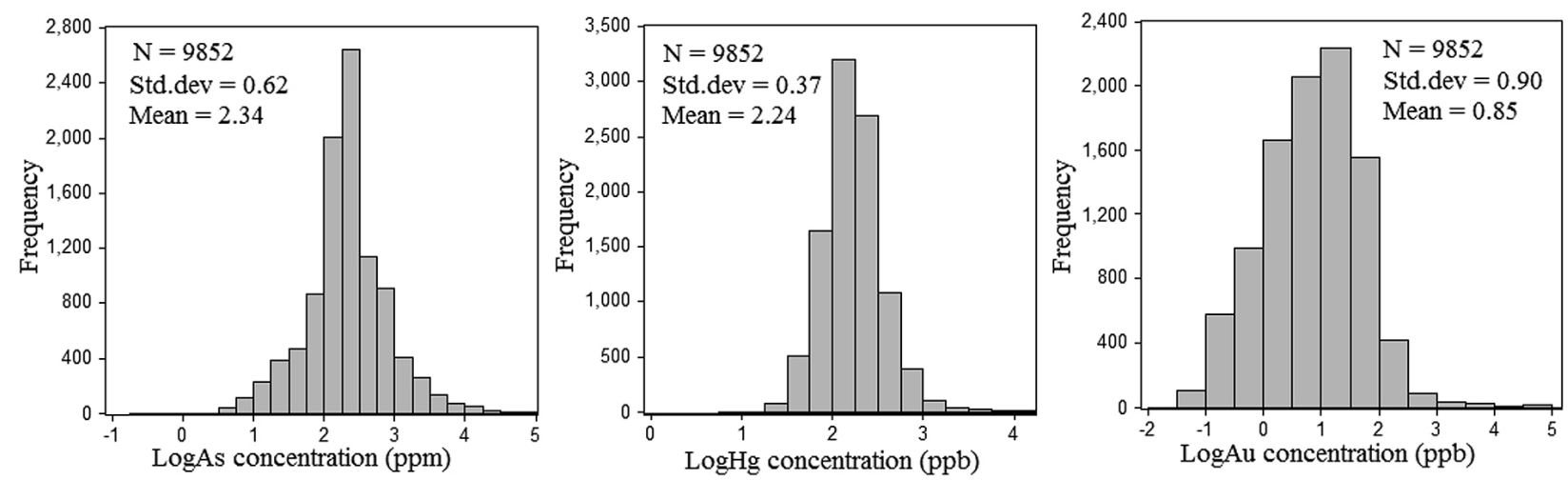

Fig. 4. Histogram displaying frequency distribution of As, $\mathrm{Hg}$ and $\mathrm{Au}$ data for the study area.
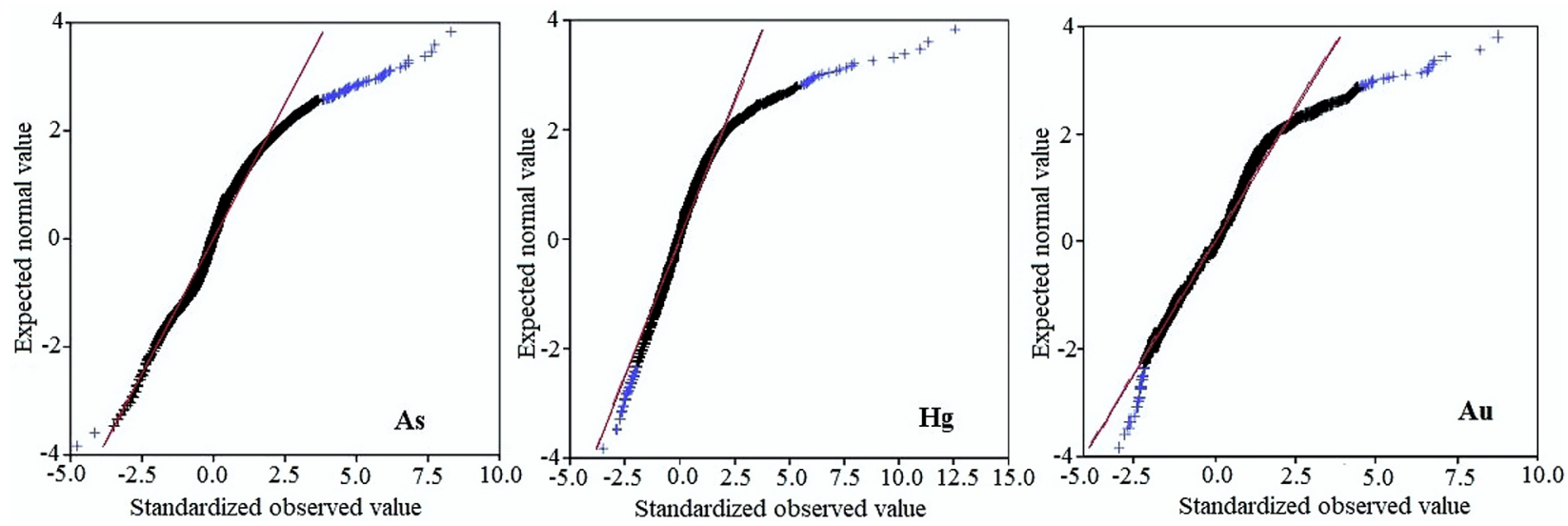

Fig. 5. Quantile-quantile plot for natural log transformed to base 10 of As, Hg and Au concentrations. Blue plus (+) are ignored outliers, prior to interpolation.

value indicate that their data sets have non-normally distributed outliers (Table 2). Particularly, the Au skewness (61.20) and kurtosis (4292.34) coefficients reach the highest point, which means that these concentration values are positively skewed (Yuan et al., 2015).

In order to normalise the data set, the log-transformed was calculated and the results are shown in Table 3 and Figure 4. The original data were plotted using q-q plot (Fig. 5) which distributes all data, both minimum and maximum, along the mean value and shows the degree of deviation of data from the mean value. This level of deviation indicates whether data are depleted or enriched in its area of origin. The quantile-quantile plot shows the uniformity and stability of data on the mean line which provides a great help in data analysis (Fig. 5).

\subsection{Quantile-quantile plot method}

Quantile-quantile is a common method used to determine the statistical frequency characteristics of data. By using this method, it is easy to identify whether the data are distributed normally or lognormally or not (Cheng et al., 2000; Yuan et al., 2015). The results of statistical analysis of As, $\mathrm{Hg}$ and $\mathrm{Au}$ concentrations show that all three elements are not normally distributed but are almost lognormal distributed, except for a few outliers that highly deviate from a straight line on low concentration and high concentration as indicated by small blue plus (+) (Fig. 5). It also indicates that this distribution is a result of mixed concentrations. According to Zuo et al. (2009), the multiple geological processes are the factors that control such kind of distribution that result in mixed concentrations. 
This linear fitting method could not represent all data on a single straight line as it shows strongly deviating data, so these data should contain multifractal characteristics (Yuan et al., 2015). The information provided in Figure 5 is helpful by giving prior knowledge in mapping singularity detailed by Cheng (2007, 2008a, 2010), Cheng \& Mao (2010), Zuo et al. (2009) and Yuan et al. $(2012,2015)$.

Point 2, as an intersection of $x$ and $y$ axes (Fig. 5), is the highest data point located on quantile-quantile plot straight line and from this value, the data slowly start deviating from a straight line. This means that the concentrations of deviating data and that of data fitting on a straight line have a large difference. The highly deviating data probably reflect the zone of high concentration. Thus, that value can be taken as a reference that all data which have values above point 2 represent samples taken from high concentrated zone.

\subsection{Kriging interpolation}

Kriging interpolation mapping was used to create a contour map which presents the spatial distribu- tion of elements. It is applied by moving a circular window with associated parameters to regulate the weighting values at nearest points. The parameters used are usually: (i) radius, (ii) decay ratio of the weighting function, (iii) maximum number of samples for each window (Cheng et al., 1994). A maximum of five samples per window have been used from which one sample is located in the centre of the window and the other four samples are neighboring points contributing to the interpolation of surface values of that location. Cross-validation generates a surface map of anomaly concentration distribution based on predictions and calculations as the result of all processes discussed in Section 3.

In the present study, median was considered as a background value (10.2 ppm for As, $9.13 \mathrm{ppb}$ for $\mathrm{Hg}$ and $2.5 \mathrm{ppb}$ for $\mathrm{Au}$ ) (Hawkes \& Webb, 1962), while the $95^{\text {th }}$ percentile considered as a threshold value (28.03 ppm for As, $16.71 \mathrm{ppb}$ for $\mathrm{Hg}$ and $8.2 \mathrm{ppb}$ for $\mathrm{Au}$ ) (Wilde et al., 2004), and all values greater than thresholds are geochemical anomalies. All the geochemical anomalies found are shown in Figure 6, based on their concentration values distinguished by different colours.
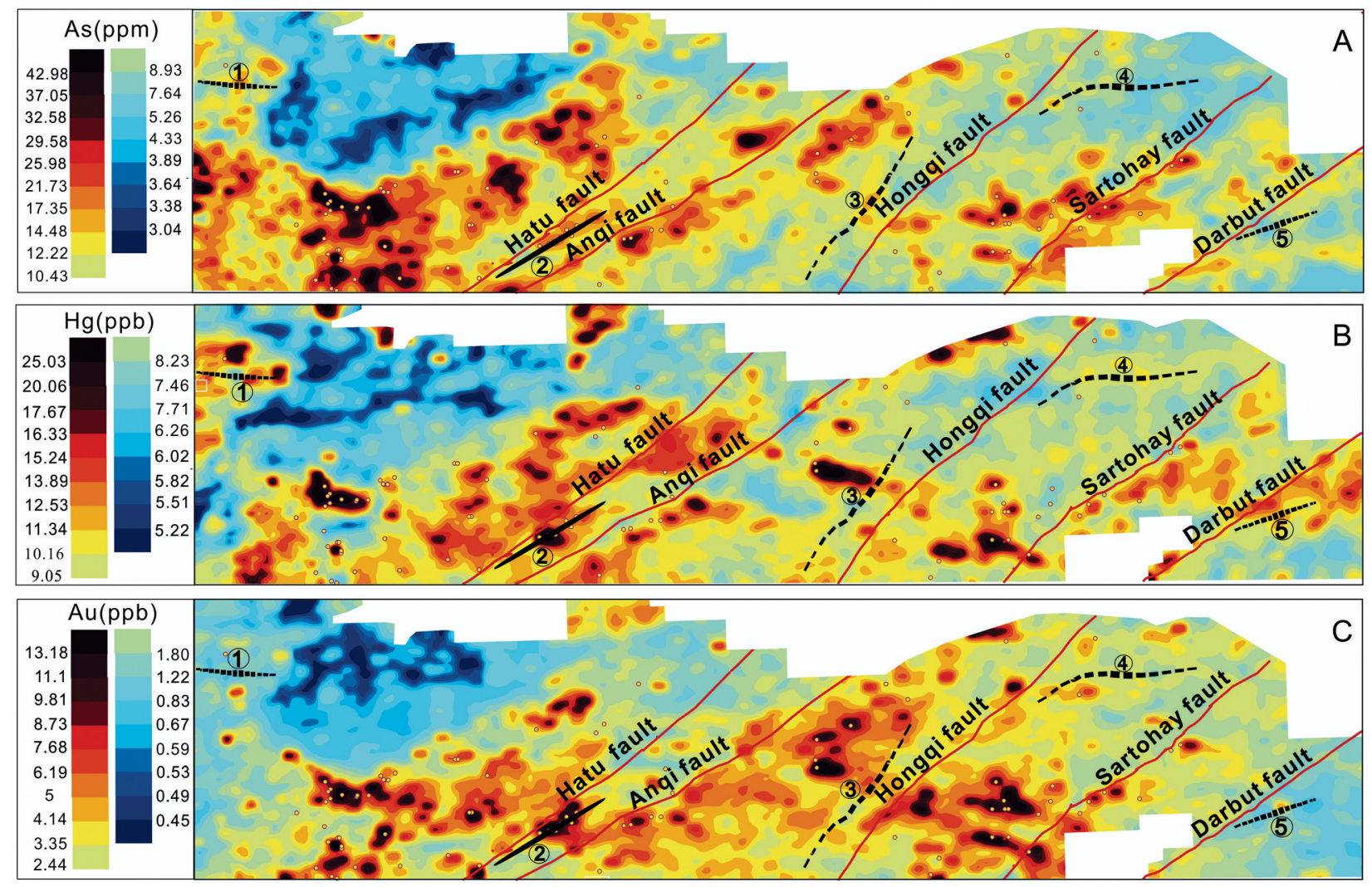

Fig. 6. Map produced by kriging interpolation to show geochemical anomalies of As, $\mathrm{Hg}$ and $\mathrm{Au}$ along with the main faults and folds: 1 - the Aketamu syncline fold; 2 - the Keketale anticline fold; 3 - the Bieluagaxi anticline fold; 4 - the Hongqi syncline fold; 5 - the Hongshan syncline fold. 

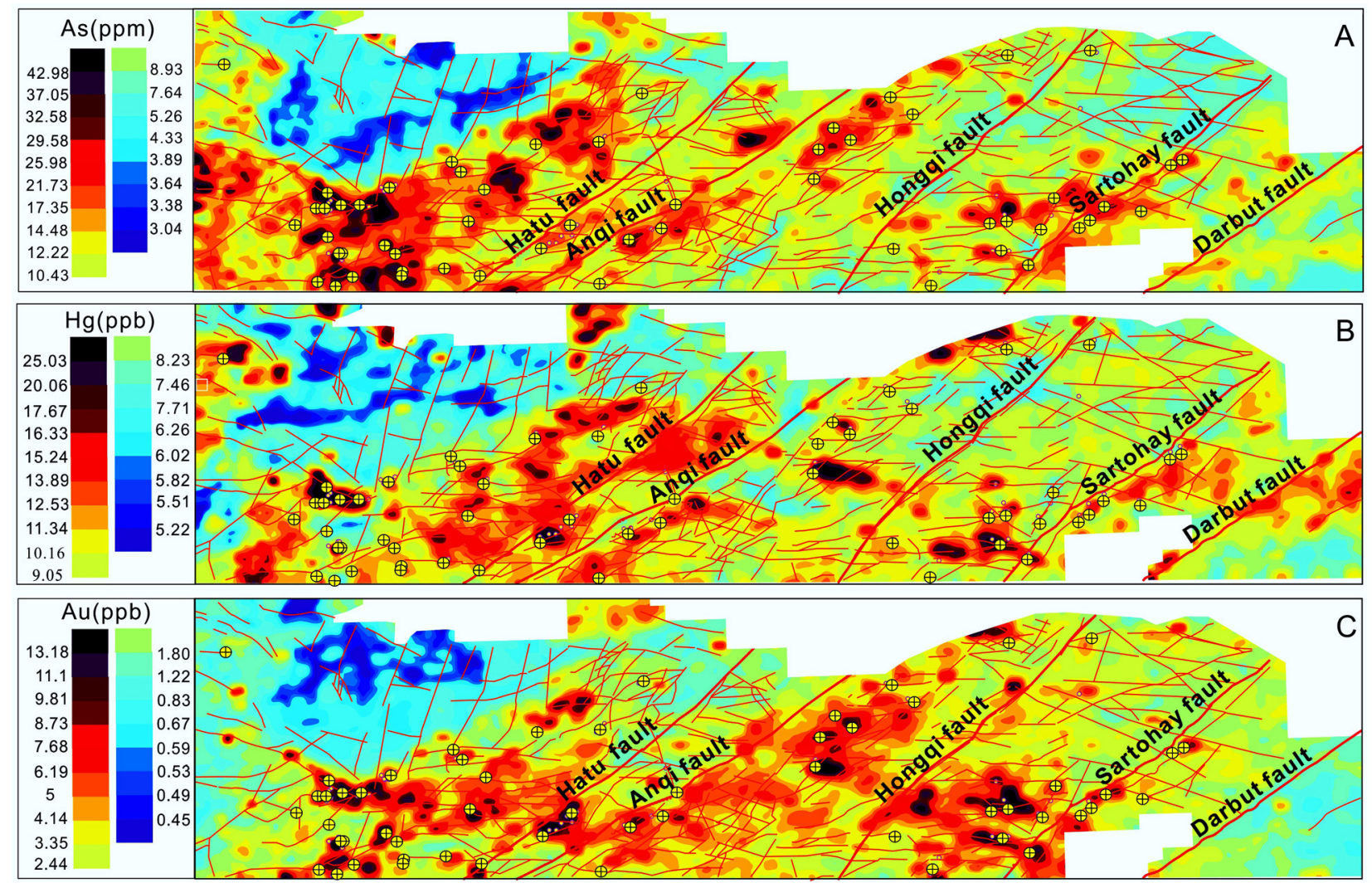

Fig. 7. Map showing location of geochemical anomalies along faults and active gold mines, as based on spatial distribution of element concentration values of $\mathrm{Au}, \mathrm{As}$ and $\mathrm{Hg}$.

The concentrations of As in the study area have a great affinity and correlation with faults, especially in the south-south-west where its high concentration relies on the Hatu fault as main fault and its related secondary faults towards to the west. It shows a high depletion of concentration in the north-north-west close to Tiechanggou where there are very few secondary faults and almost no junctions. It also shows a low concentration in the east of study area due to the lack of numerous fault junctions (Fig. 7A).

$\mathrm{Hg}$ shows that the anomaly concentration is relatively small (values greater than $16.71 \mathrm{ppb}$ ) compared to As (i.e., values $>28.03 \mathrm{ppm}$ ), but the location of their anomalies are almost in the same segments except for a few high concentration found near the Darbut fault in the south-south-east of the study area (Fig. 7B).

The spatial distribution of Au concentration indicates that high anomaly concentrations are distributed near or close to the faults, especially in junctions. There is a depletion of concentration in the northwest of the study area at Tiechanggou, not only because of faults and folds shortage, but also because that region is composed of syenogranite which does not enhance ore mineralisation. The same case was observed with these three elements in the south-south-east from the Darbut fault towards the southeast due to the lack of secondary faults.

\section{Discussion}

\subsection{Anomaly recognition}

The kriging interpolation method has become a successful approach in mineral exploration and data interpretation, in particular geochemical exploration data (Cheng, 2008b; Zuo, 2011; Yuan et al., 2012). The ordinary kriging is a linear geostatistical approach based on a stationary second-order hypothesis (Matheron, 1963; Yuan et al., 2015) and significantly delineates the spatial variability of the data set. The procedures have been discussed above and for additional detailed information, reference is made to Zhang (2005) and Ashok et al. (2007). The maps produced in the present study indicate differences in geochemical anomaly concentrations, so that we can conclude that kriging interpolation effectively identifies geochemical anomalies, and at 
the same time controls the spatial distribution of elements. The disposition of fault systems and folds indicate stress difference within geological bodies which produces the decompression of local environment. That decompression facilitates the flow of hydrothermal fluids (Zhao et al., 2016).

Geochemical data from stream sediments in this area reflect the geochemical traits of bedrock; not only are they more useful for examining geochemical anomalies related to geological bodies (Cheng, 2007; Wang et al., 2011a, b; Zhao et al., 2012), they also yield geological information on the environment they pass through (Bogoch et al., 1993; Hao et al., 2007; Brantley \& White, 2009). In a study conducted by Jiang et al. (2006), it was proved that this kind of data can be regarded as relevant sources of geo-information in geological trait identification and mapping of mineral potentials.

Based on the maps produced by the kriging method in the present study, the high and low anomaly concentrations are identified. Most of the high anomaly concentrations rely on faults and active gold mines. The location of high or low anomaly concentrations of gold is the same as both of As and $\mathrm{Hg}$. This means that both elements are closely associated to gold. These results were verified in practice by Zhao et al. (2016), who considered As, Sb and $\mathrm{Hg}$ as mineraliser elements of $\mathrm{Au}$, being mostly paragenetically associated with gold and acting in its migration as well as migrating themselves through hydrothermal fluids heading to the surface where they precipitate under suitable conditions. That migration is linked to geological processes.

Most ore deposit anomalies are formed by geological processes and originate either from heat geothermal activity or high degree of geological processes. The small distance between anomaly and heat source directly corresponds to the formation of high anomaly concentrations, and it is known that the anomalies related to mineralisation process are complex, but occasionally they can be weak or complex based on its spatial and frequency properties (Zuo et al., 2009).

\subsection{Factors of anomaly formation}

\subsubsection{Influence of fold and fault factors}

As proposed by Nigrini (1970), Lasaga et al. (1977) and Joesten (1983), the spread of metal is faster in fractured rocks than in unfractured ones due to the fact that hydrothermal fluids follow fractures along the rock. Both fractured and altered rock facilitate the formation of hidden ore when they are associated with geochemical anomalies (Liu et al., 2004).
The enrichment of $\mathrm{As}, \mathrm{Sb}$ and $\mathrm{Hg}$ can produce geochemical anomalies at the surface along faults or around the junction of the faults in all directions (Qian, 2009). Yuan et al. (2015) added that in the junction of faults or fractures zone were the two places where mostly migration stops. The same case of using fault orientation as a reference to mineralisation was used by Xiao et al. (2012), who relied on fault information for identifying and mapping geochemical anomalies linked to $\mathrm{Ag}$ and $\mathrm{Pb}-\mathrm{Zn}$ polymetallic mineralisation. Furthermore, the concealed ore deposits are formed by hydrothermal fluids across fracture systems (Liu et al., 2004). Faults and related fractures in the upper crust help in fluid migration (Sibson \& Scott, 1998) and enhance permeability which conduct hydrothermal fluids, and act as sites of ore deposition (Carranza \& Hale, 2002; Cox et al., 2001; Li et al., 2012; Micklethwaite et al., 2010). This ore-forming process generally is associated with deformation which is the main characteristic of the study area. Such a region characterised by deformation has a high permeable zone where the hydrothermal fluids pass and form simple anomalies along the temperature zone. The permeability maintained by tectonic movements in this area are crucial for the formation of hydrothermal ore mineralisation (Prokof'ev, 2000) and it was proved that the zonal temperature field is very important for localising hydrothermal mineralisation, giving direct reflection to the anomalous geochemical field. Usually, the hydrothermal gold deposits must be accompanied by a set of chemical elements, whereby they complicate the anomalous structures of geochemical fields (Voroshilov, 2009). Those anomalies associated to hydrothermal deposits undergo transformation in the development stages of hydrothermal ore metasomatic systems. In the initial mineralisation phase, ore formation is possibly associated with pressure variations which are a result of tectonic movements in the area (Voroshilov et al., 2014) and this mechanism of ore-forming hydrothermal systems influences the composition of geochemical anomalies.

Generally, an area with many faults and folds, especially in the junction of faults, shows large and high anomaly concentrations (Figs. 6, 7). This substantiates the views expressed by Risdianto et al. (2010) that the intersections of faults might create the permeability in depth and influence the flow of geothermal fluids from reservoirs; that author also added that lithology can also intervene in the control of the formation of geochemical anomalies. The abundance of faults and their junctions are associated with the strong anomalous area; this means that the increase of fault junctions strengthens anomaly concentrations. 


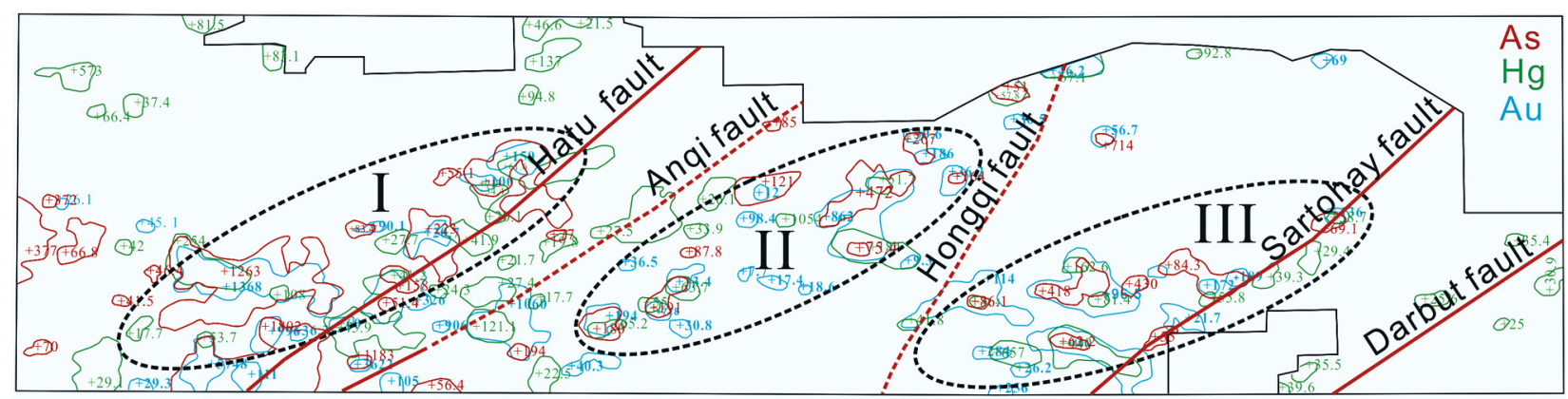

Fig. 8. Map illustrating the relationship between high geochemical anomaly concentration of As (in ppm), $\mathrm{Hg}$ (in ppb) and $\mathrm{Au}$ (in ppb), based on original concentration values in the study area. I, II \& III are the regions of high anomaly concentration.

Normally, mineralisation and distribution of ore are controlled by fault systems (Cheng et al., 2011) and it is not compulsory for the ore to be directly under the anomaly surface (Hawkes, 1976). Concentrations in the study area are controlled mainly by the Hatu and Sartohay faults and their related secondary faults. Those three element anomalies have a close relationship with high abnormal intensity, but contrary, they are affected by the Anqi, Hongqi and Darbut faults. This map, as other maps of anomalies produced by geochemical exploration techniques, is the key tool for drilling in order to locate the depth at which ore deposits occur (Hawkes, 1976).

Figure 8 illustrates the high concentrations of As (37.2-1,802 ppm), $\mathrm{Hg}(17.7-1,054 \mathrm{ppb})$ and $\mathrm{Au}$ (20-5,748 ppb). The high concentrations represented in this figure are not only oriented north-northeast-south-south-west but are also in oblique and parallel form which matches the faults' orientation in this region. The enrichment of anomalies along the main faults indicates the direction and orientation of hydrothermal fluid flows during anomaly formation. That accumulation of high concentration of these three elements has a close relationship with current geological settings, and this is linked to intense geological processes and weathering processes that occur mostly in areas which undergo numerous deformations such as mining regions, faults and fractures. Those deformations facilitate the migration and dispersion of hydrothermal fluids and haloes. Furthermore, the enrichment of anomalies shows the association of ore-forming elements which is the preliminary condition of mineralisation in this area. In such a region dominated by magmatic rock, the mineralisation is directly controlled by fault systems. Those faults involve piloting distribution of magmatism intrusion, flow of hydrothermal fluids and rock magmatism.

The distribution of $\mathrm{As}, \mathrm{Hg}$ and $\mathrm{Au}$ anomalies is found to be in the same location (Fig. 8I-III). From this perspective, the high concentration of $\mathrm{Au}$ is correlated with that of $\mathrm{As}$ and $\mathrm{Hg}$ as its pathfinders. In addition, the connection between their high anomalies also indicates that the origin and causes of their mineralisation are probably the same or one element depends on others, which proves the appellation of being a gold pathfinder.

\subsubsection{Influence of mining site factors}

However, looking at the known gold mining sites, most of the new high anomaly concentration of $\mathrm{Au}$ discovered in the present area are near or close to the mining sites. This indicates that the formation of new $\mathrm{Au}$ anomalies is influenced somehow by the current mining site or by previous mining sites through geological or weathering processes. The areas surrounding gold mine correspond to high-concentration accumulations of $\mathrm{As}, \mathrm{Hg}$ and $\mathrm{Au}$. These anomalies might have a close relationship with past and current gold mining sites. This is explained by the appearance of As-, $\mathrm{Hg}$ - and Au-depleted anomalies far from the mining areas. Seen in this light, the pathfinder elements of $\mathrm{Au}$ have high concentration anomalies as a result of intense geological processes influenced by the presence of numerous faults and fractures. Especially, the affinity between Au and As is very strong; for example, gold and arsenic appear as inclusions in arsenopyrite and chalcopyrite, which was confirmed by Huang et al. (2011). Micro- and macro-fractures may control gold mineralisation within a whole deposit or in a single ore body. Further information indicates that gold concentration is lower than its pathfinders mostly far from gold mine and faults. This kind of anomaly distribution shows that the distribution of gold and its pathfinder elements is due to primary dispersion from the host rock.

\section{Conclusions}

The present study applies geostatistical methods to bedrock and stream sediment data from West Jun- 
ggar in order to identify geochemical anomalies of $\mathrm{As}, \mathrm{Hg}$ and $\mathrm{Au}$, and determine factors governing the formation of anomalies. The findings are summarised as follows:

1. Statistical calculations successfully determine the background and threshold values which are very important during mapping of mineral potentials.

2. The kriging interpolation method showed the effectiveness in locating geochemical anomalies by performing spatial autocorrelation of data for displaying the correlation of nearest data points and predicting the value of unmeasured location.

3. The number of faults and folds, in particular their junctions, are directly proportional to the strength of geochemical anomalies; their increase or decrease in number have a significant impact on the geochemical anomaly concentration. Those faults, fracture systems and permeability together enhance an easier and faster flow of hydrothermal fluids towards the surface, which results in the formation of geochemical anomalies.

4. The newly formed Au anomalies near the known gold mining sites are influenced by the current or previous mining sites through geological or weathering processes. The lower concentration of $\mathrm{Au}$, in comparison to its pathfinders, far from gold mine and faults, is due to the fact that their anomalies are linked to primary dispersion from the host rock.

5. The accumulation of high concentrations of these three elements has a close relationship with current geological settings of the study area due to intense geological processes that mostly occur in such regions with numerous mining sites, faults and fractures.

\section{Acknowledgements}

We express thanks to the No. 1 Geological Survey Team, Xinjiang Bureau of Geology and Mineral Resource Exploration, for providing material used and data recorded in the present paper which was financially supported by the Young Star of Science and Technology Plan Projects in Shaanxi Province, China (grant no. 2016KJXX-71), the Special Fund for Basic Scientific Research of Central Colleges, Chang'an University (310827153506, 310827153407) and the China Regional Geological Survey (no. XJZBKD2008-04).

\section{References}

Abreu, N. \& Ramos, P., 2010. An integrated application for geostatistical analysis of sea outfall discharges based on R software. MTS/IEEE Seattle, OCEANS 2010, 3-8.

Aitchison, J., 1986. The statistical analysis of compositional data. Monographs on Statistics and Applied Probability. Chapman \& Hall Ltd, London, 416 pp.

An, F. \& Zhu, Y.F., 2009. Significance of native arsenic in the Baogutu gold deposit, western Junggar, Xinjiang, NW China. Chinese Science Bulletin 54, 1744-1749.

Ashok, K., Suman, M. \& Abhishek, B., 2007. Application of ArcGIS geostatistical analyst for interpolating environmental data from observations. Environmental Progress 26, 220-225.

Bogoch, R., Shirav, M., Beyth, M. \& Halicz, L., 1993. Geochemistry of ephemeral stream sediments in the Precambrian mountainous arid terrain of southern Israel. Journal of Geochemical Exploration 46, 349-364.

Bonham $\square$ Carter, G.F., Agterberg, F.P. \& Wright, D.F., 1988. Integration of geological datasets for gold exploration in Nova Scotia. Photogrammetric Engineering Remote Sensing 54, 1585-1592.

Bonham-Carter, G.F., Agterberg, F.P. \& Wright, D.F., 1989. Weights of evidence modelling: a new approach to mapping mineral potential. Statistical applications in the earth sciences $89,171-183$.

Bossew, P., Žunić Z.S., Stojanovska, Z., Tollefsen, T., Carpentieri, C., Veselinović, N., Komatina, S., Vaupoti, J., Simovi, R.D., Antignani, S., Bochicchio, F., 2014. Geographical distribution of the annual mean radon concentrations in primary schools of southern Serbia - application of geostatistical methods. Journal of Environmental Radioactivity 127, 141-148.

Brantley, S.L. \& White, A.F., 2009. Approaches to modeling weathered regolith. Reviews in Mineralogy and Geochemistry 70, 435-484.

Cao, M., Qin, K., Li, G., Evans, N.J. \& Jin, L., 2015. In situ LA-(MC)-ICP-MS trace element and Nd isotopic compositions and genesis of polygenetic titanite from the Baogutu reduced porphyry Cu deposit, Western Junggar, NW China. Ore Geology Reviews 65, 940-954.

Carranza, E.J.M., 2010. Catchment basin modelling of stream sediment anomalies revisited: incorporation of EDA and fractal analysis. Geochemistry: Exploration, Environment, Analysis 10, 365-381.

Carranza, E.J.M. \& Hale, M., 2002. Where are porphyry copper deposits spatially localized? A case study in Benguet province, Philippines. Natural Resources Research 11, 45-59.

Chen, B. \& Arakawa, Y., 2005. Elemental and Nd-Sr isotopic geochemistry of granitoids from the West Junggar fold belt (NW China), with implications for Phanerozoic continental growth. Geochimica et Cosmochimica Acta 69, 1307-1320.

Chen, J., Han, B., Ji, J., Zhang, L., Zhao, X., He, G. \& Wang, T., 2010. Zircon U-Pb ages and tectonic implications of Paleozoic plutons in northern West Junggar, North Xinjiang, China. Lithos 115, 137-152.

Cheng, Q., 2007. Mapping singularities with stream sediment geochemical data for prediction of undiscovered 
mineral deposits in Gejiu, Yunnan Province, China. Ore Geology Reviews 32, 314-324.

Cheng, Q., 2008a. Non-linear theory and power-law models for information integration and mineral resources quantitative assessments. Mathematical Geosciences 40, 503-532.

Cheng, Q., 2008b. Modeling local scaling properties for multiscale mapping. Vadose Zone Journal 7, 525-532.

Cheng, Q. \& Zhao, P., 2011. Singularity theories and methods for characterizing mineralization processes and mapping geo-anomalies for mineral deposit prediction. Geoscience Frontiers 2, 67-79.

Cheng, Q., Agterberg, F.P. \& Ballantyne, S.B., 1994. The separation of geochemical anomalies from background by fractal methods. Journal of Geochemical Exploration 51, 109-130.

Cheng, Q., Xu, Y. \& Grunsky, E., 2000. Integrated spatial and spectrum method for geochemical anomaly separation. Natural Resources Research 9, 43-52.

Cheng, Y. \& Mao, J., 2010. Age and geochemistry of granites in the Gejiu area, Yunnan province, SW China: constraints on their petrogenesis and tectonic setting. Lithos 120, 258-276.

Chow, W., 2009. A note on the geological excursion to North Xinjiang. Geological Society of Hong Kong Newsletter 15, Special Issue 2, pp. 1-7.

Cox, S.F., Knackstedt, M.A. \& Braun, J., 2001. Principles of structural control on permeability and fluid flow in hydrothermal systems. [In:] Richards, J. \& Tosdal, R. (Eds.): Deformation, fluid flow and ore deposits. Reviews in Economic Geology 14, pp. 1-24.

Deng, J., Wang, Q.F., Wan, L., Yang, L.Q., Gong, Q.J., Zhao, J. \& Liu, H., 2009. Self-similar fractal analysis of gold mineralization of Dayingezhuang disseminated-veinlet deposit in Jiaodong gold province, China. Journal of Geochemical Exploration 102, 95-102.

El-Makky, A.M., 2011. Statistical analyses of La, Ce, Nd, $\mathrm{Y}, \mathrm{Nb}, \mathrm{Ti}, \mathrm{p}$, and $\mathrm{Zr}$ in bedrocks and their significance in geochemical exploration at the um garayat gold mine area, eastern desert, Egypt. Natural Resources Research 20, 157-176.

El-Makky, A.M. \& Sediek, K.N., 2012. Stream sediments geochemical exploration in the northwestern part of Wadi Allaqi area, south eastern desert, Egypt. Natural Resources Research 21, 95-115.

Geng, H., Sun, M., Yuan, C., Xiao, W., Xian, W., \& Zhao, G., Zhang, L., Wong, K. \& Wu, F., 2009. Geochemical, $\mathrm{Sr}-\mathrm{Nd}$ and zircon U-Pb-Hf isotopic studies of Late Carboniferous magmatism in the west Junggar, Xinjiang: implications for ridge subduction. Chemical Geology 266, 364-389.

Grunsky, E.C., Mueller, U.A., \& Corrigan, D., 2014. A study of the lake sediment geochemistry of the Melville Peninsula using multivariate methods: applications for predictive geological mapping. Journal of Geochemical Exploration 141, 15-41.

Guo, D.L., 1997. Tectono-metallogenetic mechanism for the Buerkesidai gold deposit. Geotectonica et Metallogenia 21, 162-166 (in Chinese, with English abstract).

Han, B.F., Ji, J.Q., Song, B., Chen, L.H. \& Zhang, L., 2006. Late Paleozoic vertical growth of continental crust around the Junggar basin, Xinjiang, China (Part I). Timing of post-collisional plutonism. Acta Petrologica Sinica 22, 1077-1086 (in Chinese, with English abstract).

Hao, L., Lu, J., Li, L., Mo, G., Yan, G., Shi, Y. \& Zhao, Y., 2007. Method of using regional geochemical data in geological mapping in shallow overburden areas. Geology of China 34, 710-715 (in Chinese, with English abstract).

Hawkes, H.E., 1976. Exploration Geochemistry Bibliography, 1972-1975. Spec. Vol. 5, Association of Exploration Geochemistry, Toronto, $195 \mathrm{pp}$.

Hawkes, H.E. \& Webb, J.S., 1962. Geochemistry in Mineral Exploration. Harper and Row, 415 pp.

Huang, D., Wang, X., Yang, X., Li, G., Huang, S., Liu, Z. \& Qiu, R., 2011. Geochemistry of gold deposits in the Zhangbaling tectonic belt, Anhui Province, China. International Geology Review 53, 612-634.

Jahn, B.M., Wu, F.Y. \& Chen, B., 2000. Granitoids of the Central Asian Orogenic Belt and continental growth in the Phanerozoic. Transactions of the Royal Society of Edinburgh. Earth Sciences 91, 181-193.

Jiang, Y.H., Jiang, S.Y., Ling, H.F. \& Dai, B.Z., 2006. Low-degree melting of a metasomatized lithospheric mantle for the origin of Cenozoic Yulong monzogranite-porphyry, East Tibet: geochemical and $\mathrm{Sr}-\mathrm{Nd}-\mathrm{Pb}-$ Hf isotopic constraints. Earth and Planetary Science Letters 241, 617-633.

Joesten, R., 1983. Grain growth and grain-boundary diffusion in quartz from the Christmas Mountains (Texas) contact aureole. American Journal of Science 283-A, 233-245.

Lasaga, A.C., Richardson, S.W. \& Holland, H.D., 1977. The mathematics of cation diffusion and exchange under metamorphic conditions. [In:] Saxena, S.K. \& Bhattachan, S.K. (Eds.). Energetics of Geological Processes. Spring-Verlag, New York, pp. 354- 388.

Li, C., Ma, T., \& Shi, J., 2003. Application of a fractal method relating concentrations and distances for separation of geochemical anomalies from background. Journal of Geochemical Exploration 77, 167-175.

Li, N., Carranza, E.J.M., Ni, Z. \& Guo, D., 2012. The $\mathrm{CO}_{2}$ rich magmatic-hydrothermal fluid of the Qiyugou breccia pipe, Henan Province, China: implication for breccia genesis and gold mineralization. Geochemistry Exploration Environmental Analysis 12, 147-160.

Li, W., Ren, B., Yang, X., You, L., \& Chen, Q., 2002. The intermediate-acid intrusive magmatism and its geodynamic significance in eastern Tianshan region. Northwestern Geology 35, 41-64.

Liu, L.M. \& Peng, S.L., 2004. Prediction of hidden by synthesis ore bodies of geological, geophysical and geochemical information based on dynamic model in Fenghuangshan ore field, Tongling District, China. Journal of Geochemical Exploration 81, 81-98.

Liu, X.J., Xu, J.F., Wang, S.Q., Hou, Q.Y., Bai, Z.H. \& Lei, M., 2009a. Geochemistry and dating of E-MORB type mafic rocks from Dalabute Ophiolite in West Junggar, Xinjiang and geological implications. Acta Petrologica Sinica 25, 1373-1389 (in Chinese, with English abstract). 
Liu, Y., Guo, L., Liu, Y., Song, H., Song, B., Zhang, R., Xu, F. \& Zhang, Y., 2009b. Geochronology of Baogutu porphyry copper deposit in western Junggar area, Xinjiang of China. Science in China 52, 1543-1549.

Luz, F., Mateus, A., Matos, J.X. \& Gonçalves, M.A., 2014. $\mathrm{Cu}$ - and $\mathrm{Zn}$-soil anomalies in the NE Border of the South Portuguese Zone (Iberian Variscides, Portugal) identified by multifractal and geostatistical analyses. Natural Resources Research 23, 195-215.

Ma, T.H., Li, C.J. \& Lu, Z.M., 2014. Estimating the average concentration of minor and trace elements in surficial sediments using fractal methods. Journal of Geochemical Exploration 139, 207-216.

Ma, T., Li, C. \& Lu, Z., 2016. Geographical environment determinism for discovery of mineral deposits. Journal of Geochemical Exploration 168, 163-168.

Matheron, G., 1963. Principles of geostatistics. Economic Geology 58, 1246-1266.

Micklethwaite, S., Sheldon, H.A. \& Baker, T., 2010. Active fault and shear processes and their implications for mineral deposit formation and discovery. Journal of Structural Geology 32, 151-165.

Monego, M., Ramos, P. \& Neves, M.V., 2008. Geostatistical Mapping of Outfall Plume Dispersion Data Gathered with an Autonomous Underwater Vehicle. Geo ENV VII - Geostatistics for Environmental Applications. Springer 16, 199-209.

Mwangi, S.M., 2013. Application of geochemical methods in geothermal exploration in Kenya. Procedia Earth $\mathcal{E}$ Planetary Science 7, 602-606.

Nigrini, A., 1970. Diffusion in rock alteration systems: I. Predications of limiting equivalent ionic conductances at elevated temperatures. American Journal of Science 269, 65-91.

Pebesma, E.J. \& Wesseling, C.G., 1998. Gstat: a program for geostatistical modelling, prediction and simulation. Computers \& Geosciences 24, 17-31.

Prokof'ev, V.Y., 2000. Geochemistry of ore-forming fluids of hydrothermal gold deposits of various genetic types from the study of fluid inclusions. Nauka, Novosibirsk, pp.1-34 (in Russian).

Qian, J.P., 2009. Tectono-geochemical prospecting method and its application in searching for sediment-hosted, disseminated gold deposits. Geology E Exploration 45, 60-67 (in Chinese, with English abstract).

Raines, G.L., 2008. Are fractal dimensions of the spatial distribution of mineral deposits meaningful? Natural Resources Research 17, 87-97.

Ramos, P. \& Abreu, N., 2010. Spatial analysis of sea outfall discharges using block kriging. Water Research Conference. Lisbon, Portugal 1, 1-16.

Risdianto, D. \& Kusnadi, D., 2010. The Application of a Probability Graph in Geothermal Exploration. Proceedings of World Geothermal Congress. Bali, Indonesia, 25-29.

Rui, Z., Goldfarb, R.J., Qiu, Y., Zhou, T., Chen, R., Pirajno, F. \& Yun, G., 2002. Paleozoic-Early Mesozoic gold deposits of the Xinjiang Autonomous Region, northwestern China. Mineralium Deposita 37, 393-418.

Seltmann, R. \& Porter, T.M., 2005. The porphyry Cu-Au/ Mo deposits of Central Eurasia I. Tectonic, geologic and metallogenic setting, and significant deposits. [In:]
Porter, T.M. (Ed.): Super porphyry copper and gold deposits: A Global Perspective. vol. 2. Porter Geo-Consultancy (PGC) Publishing, Adelaide, pp. 467-512.

Shen, P., Pan, H. \& Zhu, H., 2016. Two fluid sources and genetic implications for the Hatu gold deposit, Xinjiang, China. Ore Geology Reviews 73, 298-312.

Shen, P., Shen, Y., Liu, T., Li, G. \& Zeng, Q., 2007. Genesis of volcanic-hosted gold deposits in the Sawur gold belt, northern Xinjiang, China: evidence from REE, stable isotopes, and noble gas isotopes. Ore Geology Reviews. 32, 207-226.

Shen, P., Xiao, W.J., Pan, H.D., Chen, X.H., Seitmuratova, E. \& Shen, Y.C., 2013. Petrogenesis and tectonic settings of the Late Carboniferous Jiamantieliek and Baogutu ore-bearing porphyry intrusions in the southern west Junggar, NW China. Journal of Asian Earth Sciences $75,158-173$.

Shen, P., Zhou, T.F., Yuan, F., Pan, H.D., Wang, J.L. \& Eleonora, S., 2015. Main deposit types, mineral systems and metallogenic belt connections in the circumbalkhash-west Junggar metallogenic province. Acta Petrologica Sinica 31, 285-303.

Shen, Y.C., Jin, C.W. \& Zhang, X.Q., 1993. The relationships of magma activity and tectonic setting with gold mineralization in west Junggar. [In:] Tu, G.Z. (Ed.): New Improvement of Solid Geosciences in Northern Xinjiang. Science Press, Beijing, pp. 137-150.

Sibson, R.H. \& Scott, J., 1998. Stress/fault controls on the containment and release of over-pressured fluids: Examples from gold-quartz vein systems in Juneau, Alaska; Victoria, Australia and Otago, New Zealand. Ore Geology Reviews 13, 293-306.

Singer, D.A., Menzie, W.D., Sutphin, D.M., Mosier, D.L. \& Bliss, J.D., 2001. Mineral deposit density - An update. [In:] Schulz, K.J. (Ed.): Contributions to global mineral resource assessment research. U.S. Geological Survey Professional Paper 1640-A, p. A1-A13.

Su, Y.P., Tang, H.F. \& Hou, G.S., 2006. Geochemistry of aluminous A-type granites along Darabut tectonic belt in the west Junggar, Xinjiang. Geochimica 35, 55-67.

Tan, J.J. \& Zhu, Y.F., 2010. Study on Fe-Ni-As-S mineral assemblages in Sartohay chromite deposit, Xinjiang, China. Acta Petrologica Sinica 26, 2264-2274 (in Chinese, with English abstract).

Tang, G.J., Wyman, D.A., Wang, Q., Li, J., Li, Z.X., \& Zhao, Z.H. \& Sun, W.D., 2012. Asthenosphere-lithosphere interaction triggered by a slab window during ridge subduction: trace element and $\mathrm{Sr}-\mathrm{Nd}-\mathrm{Hf}-\mathrm{Os}$ isotopic evidence from Late Carboniferous tholeiites in the Western Junggar area (NW China). Earth $\mathcal{E}$ Planetary Science Letters 329-330, 84-96.

Voroshilov, V.G., 2009. Anomalous structures of geochemical fields of hydrothermal gold deposits: Formation mechanism, methods of geometrization, typical models, and forecasting of ore mineralization. Geology of Ore Deposits 51, 1-16.

Voroshilov, V., Savinova, O., Ananev, Y., \& Abramova, R., 2014. Anomaly geochemical fields in Siberian hydrothermal gold deposits. Institute of Physics (IOP) Conference Series: Earth and Environmental Science 21. https:/ / doi.org/10.1088/1755-1315/21/1/012009 
Wang, J., Wang, Y. \& Wang, L., 2004. The Junggar immature continental crust province and its mineralization. Acta Geologica Sinica 78, 337-344 (in Chinese, with English abstract).

Wang, Q., Deng, J., Liu, H., Wang, Y., Sun, X. \& Wan, L., 2011a. Fractal models for estimating local reserves with different mineralization qualities and spatial variations. Journal of Geochemical Exploration 108, 196-208.

Wang, W., Zhao, J. \& Cheng, Q., 2011b. Analysis and integration of geo-information to identify granitic intrusions as exploration targets in southeastern Yunnan District, China. Computers \& Geosciences 37, 1946-1957.

Wang, X.B., 2005. Analysis of the geology and genesis of Yamansu Fe deposit. Contributions to Geology \& Mineral Resources Research 20, 125-128. (in Chinese, with English abstract).

Wilde, A.R., Bierlein, F.P. \& Pawlitschek, M., 2004. Lithogeochemistry of orogenic gold deposits in Victoria, se Australia: a preliminary assessment for undercover exploration. Journal of Geochemical Exploration 84, 35-50.

Xiao, F., Wang, C., Chen, J., Zhang, Z., Wu, G. \& Agterberg, F.P., 2012. Singularity mapping and spatially weighted principal component analysis to identify geochemical anomalies associated with $\mathrm{Ag}$ and $\mathrm{Pb}-\mathrm{Zn}$ polymetallic mineralization in northwest Zhejiang, China. Journal of Geochemical Exploration 122, 90-100.

Yakubchuk, A., 2004. Architecture and mineral deposit settings of the Altaid orogenic collage: a revised model. Journal of Asian Earth Sciences 23, 761-779.

Yang, G., Li, Y., Santosh, M., Yang, B., Zhang, B. \& Tong, L., 2013. Geochronology and geochemistry of basalts from the Karamay ophiolitic melange in west Junggar (NW China): implications for Devonian-Carboniferous intra-oceanic accretionary tectonics of the southern altaids. Bulletin of the Geological Society of America 125, 401-419.

Yang, G., Li, Y., Xiao, W., \& Tong, L., 2015. OIB-type rocks within west Junggar ophiolitic mélanges: evidence for the accretion of seamounts. Earth-Science Reviews 150, 477-496.

Yang, G.X., Li, Y.J., Tong, L.L., \& Li, G.Y., 2017. The formation mechanism of accretionary wedge at Karamay in west Junggar, NW China. Science China Earth Sciences 60, 546-556.

Yin, J., Yuan, C., Sun, M., Long, X., Zhao, G., Wong, K.P., Geng, H. \& Cai, K., 2010. Late Carboniferous high-Mg dioritic dikes in western Junggar, NW China: geochemical features, petrogenesis and tectonic implications. Gondwana Research 17, 145-152.

Yin, Y., Chen, D., An, Y., Li, J., Fan, Y., You, Z. \& Yang, J., 1996. Characteristics of the Kuoerzhenkuola epithermal gold deposit in Sawuershan, Xinjiang. Geological Exploration for Non-ferrous Metals 5, 278-283 (in Chinese, with English abstract).

Yuan, F., Zhou, T., Tan, L., Fan, Y., Yang, W., He, L. \& Yue, S., 2006. Isotopic ages of the I-type granites in west Junggar Sawuer region. Acta Petrologica Sinica 22, 1238-1248.

Yuan, F., Li, X., Jowitt, S.M., Zhang, M., Jia, C., Bai, X. \& Zhou, T., 2012. Anomaly identification in soil ge- ochemistry using multifractal interpolation: a case study using the distribution of $\mathrm{Cu}$ and $\mathrm{Au}$ in soils from the Tongling Mining District, Yangtze metallogenic belt, Anhui Province, China. Journal of Geochemical Exploration 116-117, 28-39.

Yuan, F., Li, X., Zhou, T., Deng, Y., Zhang, D., Xu, C., Zhang, R., Jia, C. \& Jowitt, S. M., 2015. Multifractal modelling-based mapping and identification of geochemical anomalies associated with $\mathrm{Cu}$ and Au mineralisation in the NW Junggar area of northern Xinjiang Province, China. Journal of Geochemical Exploration 154, 252-264.

Zhang, J., Xiao, W., Han, C., Mao, Q., Ao, S., Guo, Q. \& Ma, C., 2012. A Devonian to Carboniferous intra-oceanic subduction system in western Junggar, NW China. Institute of Geology and Geophysics CAS 125, pp. 592-606.

Zhang, L., Sun, M. \& Xu, B., 2001. Phase relations in garnet-bearing metabasites of prehnite-pumpellyite facies from the Darbut-Sartuohay ophiolite, western Junggar of Xinjiang, China. Mineralogy \& Petrology 71, 67-85.

Zhang, L.C., Bo, W., Jiao, X.J. \& Rui, Z., 2006. Characteristics and geological significance of adakitic rocks in copper-bearing porphyry in Baogutu, western Junggar. Geology in China 33, 626-631 (in Chinese, with English abstract).

Zhang, R., 2005. The Theory and Application of Spatial Variation. Science Press, Beijing, 188 pp.

Zhao, J., Wang, W., Cheng, Q. \& Agterberg, F., 2016. Mapping of Fe mineral potential by spatially weighted principal component analysis in the eastern Tianshan Mineral District, China. Journal of Geochemical Exploration 164, 107-121.

Zhao, J., Wang, W., Dong, L., Yang, W. \& Cheng, Q., 2012. Application of geochemical anomaly identification methods in mapping of intermediate and felsic igneous rocks in eastern Tianshan, China. Journal of Geochemical Exploration 122, 81-89.

Zhu, B., \& Feng, Y., 1994. Plate tectonics and evolution in west Junggar of Xinjiang. Xinjiang Geology 12, 91-105.

Zhu, Y.F., 2014. Geological evolution and division of giant metallogenic belts in core part of Central Asian Metallogenic Region. Mineral Deposits 33, 471-485 (in Chinese, with English abstract).

Zhu, Y.F. \& Xu, X., 2007. Exsolution texture of two-pyroxenes in lherzolite from Baijiangtan ophiolitic mélange, western Junggar, China. Acta Petrologica Sinica 23, 1075-1086 (in Chinese, with English abstract).

Zuo, R., 2011. Identifying geochemical anomalies associated with $\mathrm{Cu}$ and $\mathrm{Pb}-\mathrm{Zn}$ skarn mineralization using principal component analysis and spectrum-area fractal modeling in the Gangdese Belt, Tibet (China). Journal of Geochemical Exploration 111, 13-22.

Zuo, R., Cheng, Q., Agterberg, F.P. \& Xia, Q., 2009. Application of singularity mapping technique to identify local anomalies using stream sediment geochemical data, a case study from Gangdese, Tibet, western China. Journal of Geochemical Exploration 101, 225-235.

Manuscript submitted 26 February 2018 Revision accepted 15 June 2018 